In addition to the scientific activities, a number of interesting social events and excursions was arranged which included a trip to the Inca ruins at Tihuanaco and an airborne excursion to the headwaters of the Amazon, by courtesy of the Bolivian Air Force.

No such gathering would have been possible but for the existence of the Laboratorio de Física Cósmica at Chacaltaya, to the director of which, Prof. Ismael Escobar, goes the credit for its foundation and expansion into its now pre-eminent position as a high-altitude observatory, where many nations co-operate to discover some of the characteristics of the space in which we move.

C. J. BLAND

\title{
NEW NATURE RESERVES AND EXTENSIONS IN ENGLAND AND SCOTLAND
}

$\mathrm{T}$ HE Nature Conservancy declared the following new National Nature Reserves and extensions on September 28:

\section{ENGLAND}

\section{Colt Park Wood, Yorkshire}

This Reserve, at Ribblehead in the Craven Pennines, has been purchased by the Nature Conservaney and is a 21-acre strip of ash wood growing on a narrow, mile-long scar on the lower slopes of the north-east face of Ingleborough, at a height of $1,100 \mathrm{ft}$. It is only about $1 \frac{1}{2}$ miles from Ling Gill National Nature Reserve which was declared in 1958. The Reserve, which is in the Yorkshire Dales National Park, contains one of the few remaining examples of highlevel ash wood on limestone pavement. The northern part is dominated by ash varying in height from 25 to $40 \mathrm{ft}$. Other tree species include bird cherry, silver birch, rowan and hazel. The trees grow directly on the limestone, rooting in the fissures or 'grikes' which dissect the pavement deeply. Farther south along the scar the wood thins out and the clints are devoid of plant cover although a 'woodland' ground flora persists in the shelter of the grikes. The ground flora throughout the Reserve is most striking and a number of rare species is present. For a long time the wood has been valued for its shelter in an otherwise almost tree-less landscape, a fact which may explain its survival; but it has suffered extensively from grazing and little tree regeneration is taking place. The first step in management, therefore, will be to fence the Reserve to encourage fresh tree growth to replace the present ageing canopy.

Access is by permit only. Applications to visit or for permission to undertake research or to collect specimens of plants or animals should be addressed to the Regional Officer for the North Merlowood Research Station, Grange-over-Sands, Lancashire.

\section{Blean Woods (Grimshill Wood Extension) Kent}

The first part of this Reserve was declared in 1953, and a small portion added in 1959 brought the Reservo up to 81 acres. A further 84 acres, known as Grimshill Wood, have been purchased. The Reserve consists almost entirely of oak woodland with a variety of coppice species, but there is considerable diversity in the area owing to the different types of management to which each part has been subjected. That part previously declared had been undor management for coppice, whereas the newly acquired portion has been cut much less frequently and the coppice is therefore larger and older. The new area will be suitable for relatively quick conversion to highcanopy woodland, and will thus enable some of the previously declared part of the Reserve to be released for short rotation coppice management for which it is better suited.

Application for permits to visit parts of the Reserve away from public footpaths should be addressed to the Regional Officer for the South-East, the Nature Conservancy, 19 Belgrave Square, London, S.W.1.

\section{SCOTLAND}

\section{St. Cyrus, Angus and Kincardineshire}

The St. Cyrus National Nature Reserve occupies 227 acres of coastal land between the estuary of the River North Esk northward to the mouth of the Woodston Burn. It consists of a sandy foreshore, with rocks at the north end, a line of dunes, a salt marsh (a former channel of the North Esk), dune pasture and cliffs. The cliffs reach a height of $200 \mathrm{ft}$; ; southwards of St. Cyrus village they lie inland behind the dunes, but at the north end of the Reserve they rise directly from a rocky foreshore. The primary interest of the Reserve is botanical. More than 300 species of plants are recorded for the area, many of these being near the northern limits of their range in Britain. The physical features, good soil, and climate combine to favour the establishment of a variety of plant communities remarkably rich in species for such a coastal strip in north-east Scotland. The cliffs support a particularly attractive and interesting flora, with more than 170 species of flowering plants, including clustered campanula, great mullein, hemp agrimony, henbane, viper's bugloss, Nottingham catchfly, marjoram, hairy violet and maiden pink.

The Reserve was declared by nature reserve agreements with the owners, the Tay Salmon Fisheries Co., Ltd., and Joseph Johnston and Sons.

\section{Beinn Eighe (Extension), Ross and Cromarty}

This fifty-seven acre strip of pinewood and moorland between the main Kinlochewe-Gairloch road (A.832) and the shore of Loch Maree runs from the east end of the Loch to the estuary of the Grudie River. The Beinn Eighe Reserve, the first in Britain, was established in 1951 primarily for the protection and rehabilitation of Coille na Glas Leitire, the relict pinewood on the west side of the main road from which, by historical accident, the present area had been severed under different ownership. The new addition is ecologically an integral part of the main woodland, and contains some fine mature Scots pine with flora and fauna characteristic of western pinewoods, and of the loch margin. Included in the fauna are the pine marten, wild cat and crossbill.

The extension was declared under a nature reserve agreement with the owner, Colonel W. H. Whitbread. 


\section{Inverpolly (Knockan Cliff Extension), Western Ross}

The impressive crag of Knockan Cliff runs for just more than a mile along the Ullapool-Elphin road and its southern end has been acquired as an extension to the east side of the Inverpolly National Nature Reserve. This small extension of 36 acres includes one of the most important and frequently visited geological localities in Britain. The west-facing cliff rises about $250 \mathrm{ft}$. above the road and exposes a sequence of rolatively undisturbed Cambrian sediments overlain by Moine schists brought westwards for a distance of several miles by the Moine Thrust-one of the principal structural features of north-western Europe. The seemingly anomalous relationship of the sedimentary and metamorphic rocks has been investigated by geologists for more than a century and the discovery of the true oxplanation (suggosted by Nicol as long ago as 1861) played a vital part in elucidating the structure of the Scottish Highlands and in the development of the science of tectonics.

The area has been purchased by the Nature Conservancy.

\section{Loch Druidibeg (Extension), Inverness-shire}

The extension comprises 1,568 acres of enclosed ground, machair, sand-dunes and sandy shore with a complex of lochs and watercourses in the crofting townships of Stilligarry and Dremisdale, and part of Drimore Farm, South Uist. It is an extension to the Loch Druidibeg National Nature Reserve (hitherto 2,577 acres) which is owned by the Conservaney. The Reserve was established in 1958 to protect the most important breoding ground in Britain of the native grey lag goose, but the ground then acquired covored only half the area used by the geoso which nest by moorland waters in the Reserve and take their broods for rearing to the richer machair lochs of the extension. Throughout the year the geese use the original Reserve for roosting and as a refuge; the oxtension, which is part of a private estate, safoguards their feeding grounds.

In addition to containing this unique population of geese, Loch Druidibog with its extension is a comprehensive Outer Hebridean nature reserve containing moorland, in-bye croftland, machair, dunes and shore. Loch Druidibeg and the neighbouring machair and lochs within the extension constitute one of the finest and most varied samples of this Outer Hebri. dean system remaining in a comparatively unspoilt state. The extonsion has a rich flora and fauna characteristic of the machair grasslands of the Outer Hebrides, which contrast with the very different flora and fauna of Loch Druidibeg, its islands and surrounding moorland. The whole area presents fine research opportunities for studying the ecology and management of grey lag geese and other wildfowl, machair and dune communities, and the physiography of sand-dunes.

The Warden of the Loch Druidibeg Nature Reserve and extension is Mr. M. MacRury. He is a local crofter and his duties include patrolling, fire prevention, prevention of damage to crops by geese, reception of visitors, liaison with crofters and co-operation with the staff of the South Uist Estates.

A nature reservo agreement in respect of the extension was concluded between the Conservancy and the owners of South Uist Estates. The crofters of the Stilligarry and Dremisdale townships and the tenants of Drimore Farm were included in the consultations.

\section{Tentsmuir Point (Extension), Fife}

The extension to the Tentsmuir Point Nature Reserve increases the area from 92 acres to 1,249 acres. The original Reserve doclared in 1954 consisted only of land above the high-water mark. The interest here is chiefly physiographical and botanical, for excoptionally rapid accretion has resulted in a considerable area being won from the sea by natural processes of duno formation and their subsequent stabilization by sand-fixing grasses. Behind the seaward dunes are other dunes showing more advanced stages of plant colonization, and between them are wet slacks, some in process of colonization by alder and birch. The new extension consists mainly of foreshore brought within the Reserve by agreement with the Crown Estate Commissioners; within this area lie the Abertay Sands, a winter roost for wildfowl, including geose, so that Tentsmuir Point Nature Reserve is now both a nature resorve and a wildfowl refuge in which shooting will be prohibited. The extension also includes an area of 24 acres at the southern end containing samples of alder and willow slacks not represented in the existing reserve. It has been purchased from the Forestry Commission, together with a narrow strip of 12 acres of marshy ground along the western boundary.

\section{RADIO TELESCOPE ENGINEERING}

\begin{abstract}
A RECENTLY published articlo by Mr. Jacob Feld* describes some of the engineering problems concerned in the design of radio telescope structures and where these problems differ from those encountered in normal structures. It is thus of value not only to the engineer but also to the scientist, who is able to appreciate more fully the difficulties which have to be overcome in satisfying the somewhat exacting requirements demanded by this rolativoly new science.

The introductory chapter outlines the new radio astronomy techniquos, its purposes and possibilities,

* Annals of the New York Academy of Sciences. Vol. 93, Article 10: Radio Telescope Structures, By Jacob Feld. Pp. 351-456. (Xew York: New York Academy of Sciences, 1962.)
\end{abstract}

and indicates that requests for reflector surfaces of even greater accuracy are inevitable as the performance of recoiving equipment and amplifiers continues to improve.

The application and adaptation of radar reflectors for radio astronomical purposes is described in the succeeding chapter and the need for now designs emphasized because of the unprecedented size of new structures and the extreme precision required in rates of motion and angular accuracy of control.

Some of the problems associated with wind loading and the differences in approach from normal structural design are dealt with later. It is made clear that the shape of radio telescope reflectors must be maintained under operating wind and temperature 